\title{
Aplikasi Tepung Walur (Amorphophallus campanulatus var. sylvetris) dalam Pembuatan Mie dan Cookies
}

\section{Application of Walur Flour (Amorphophallus campanulatus var. sylvetris) in Noodle and Cookies}

\author{
Nandi Sukri ${ }^{1 *}$, Feri Kusnandar ${ }^{2}$, Eko Hari Purnomo ${ }^{2}$, dan Risfaheri ${ }^{3}$ \\ ${ }^{1}$ Dep. Teknologi Industri Pangan, FTIP UNPAD; \\ ${ }^{2}$ Dep. Ilmu dan Teknologi Pangan, Fateta IPB; \\ ${ }^{3}$ Balai Besar Litbang Pascapanen Pertanian Bogor \\ E-mail korespondensi: nandi@unpad.ac.id
}

\begin{tabular}{l} 
AR T I C LE IN F O \\
\hline Article history \\
Received: 10 Juni 2016 \\
Accepted: 21 Juli 2016 \\
Available online: Februari 2017 \\
\hline Keywords: \\
walur flour \\
noodle \\
cookies. \\
\hline
\end{tabular}

Kata kunci :

tepung walur

mie

cookies

\begin{abstract}
A B STR A C T
Walur (Amorphophallus campanulatus var. sylvestris) is a source of carbohydrate that locally available and potentially to be developed as a food source. The objective of this research was to produce noodle and cookies from walur flour that the oxalate contain was already reduced. The experiment was conducted by the completely randomized design with 1 factor, where the substitution proportion of walur flour consist of 4 levels and 2 repetitions, i.e., 0\%, 10\%, 20\%, 30\% for noodle and 5 levels and 2 repetitions, i.e., 0\%, 25\%, 50\%, 75\%, 100\% for cookies. The results showed that noodles product with $30 \%$ walur flour substitution and cookies product with 50\% walur flour substitution were still sensory acceptable.
\end{abstract}

\begin{abstract}
A B S T R A K
Walur (Amorphophallus campanulatus var. sylvestris) merupakan salah satu komoditas lokal sebagai sumber karbohidrat yang potensial untuk dikembangkan. Tujuan penelitian ini adalah untuk membuat produk mie dan cookies dari tepung walur yang sudah direduksi oksalatnya sebagai pensubstitusi tepung terigu. Eksperimen dilakukan dalam Rancangan Acak Lengkap Satu Faktor dengan perlakuan persentase substitusi tepung walur yang terdiri dari 4 taraf perlakuan dan 2 kali ulangan, yaitu $0 \%, 10 \%, 20 \%, 30 \%$ dalam pembuatan mie dan 5 taraf perlakuan dan 2 kali ulangan, yaitu $0 \%, 25 \%, 50 \%, 75 \%, 100 \%$ dalam pembuatan cookies. Hasil penelitian menunjukkan bahwa produk mie dengan persen substitusi tepung walur $30 \%$ dan produk cookies dengan persen subtitusi tepung $50 \%$ masih dapat diterima secara sensori.
\end{abstract}

\section{Pendahuluan}

Sebagian besar bahan pangan yang dikomsumsi di Indonesia berbahan dasar tepung terigu. Produk olahan tepung terigu seperti mie, cookies, roti dan biskuit telah menjadi menu harian pada sebagian orang. Konsumsi produk olahan berbasis tepung terigu yang sangat tinggi menjadikan tepung terigu sebagai bahan pangan pokok setara beras. Namun, sebagian besar pemenuhan kebutuhan tepung terigu dalam negeri berasal dari tepung terigu impor. Ketergantungan terhadap tepung terigu impor merupakan salah satu permasalahan yang dihadapi negara Indonesia. Oleh karena itu, perlu dilakukan suatu upaya untuk menyikapi permasalahan ini dalam memperjuangkan kemandirian pangan serta menjaga stabilitas ketahanan pangan.

Diversifikasi bahan pangan pokok berbasis bahan pangan lokal adalah salah satu upaya yang dapat dilakukan untuk mengurangi ketergantungan terhadap tepung terigu impor. Kelompok umbi-umbian memiliki potensi yang besar sebagai bahan pangan alternatif untuk dikembangkan sebagai pengganti tepung terigu. Salah satu kelompok umbi-umbian yang potensial untuk dikembangkan adalah walur. Walur termasuk kedalam family Araceae, genus Amorphophallus, dan spesies Amorphophallus campanulatus var. sylvetris. Menurut Ohtsuki (1968), Amorphophallus campanulatus mengandung kadar pati yang tinggi yaitu sekitar $77 \%$. Melihat potensi umbi walur yang cukup besar untuk dikembangkan, perlu dilakukan suatu pengkajian terhadap umbi walur sehingga dapat menghasilkan produk olahan umbi walur yang bermutu, berdaya saing dan memiliki nilai tambah yang tinggi seperti pemanfaatan tepung walur dalam pembuatan mie dan cookies. Tujuan umum dari penelitian ini adalah untuk mempelajari produksi mie dan cookies dari tepung walur yang telah direduksi kandungan oksalatnya sehingga dapat dimanfaatkan sebagai sumber pangan alternatif. 


\section{Bahan dan Metode}

Bahan utama penelitian ini adalah tepung umbi walur (Amorphophallus campanulatus var. sylvetris) yang telah direduksi kandungan oksalatnya berdasarkan penelitian Sukri (2014). Bahan pendukung yang digunakan antara lain tepung terigu, guar gum, garam, gula halus, margarindan bahan-bahan kimia untuk analisa. Peralatan yang digunakan antara lain: oven, texture analyzer, noodle processing machine, oven baking, varimixer dan peralatan gelas untuk analisa.

Aplikasi Tepung Walur pada Produk Mie dan Cookies

Aplikasi tepung walur pada pengolahan mie dan cookies adalah sebagai pensubstitusi terigu. Persentase substitusi yang digunakan pada pembuatan mie adalah 0 , 10, 20 dan $30 \%$, dan dalam pembuatan cookies adalah 0 , 25, 50, 75 dan 100\%. Selanjutnya, pada produk mie dilakukan analisis tektur, waktu optimum pemasakan, kehilangan padatan selama pemasakan dan uji sensori. Pada produk cookies dilakukan analisis tekstur dan uji sensori. Skor penilaian yang digunakan pada uji sensori terdiri dari 7 tingkat, yaitu skor 1 (sangat tidak suka), 2 (tidak suka), 3 (agak tidak suka), 4 (netral), 5 (agak suka), 6 (suka) dan 7 (sangat suka). Tahapan proses pembuatan mie kering walur dan cookies walur dapat dilihat pada Gambar 1 dan 2.

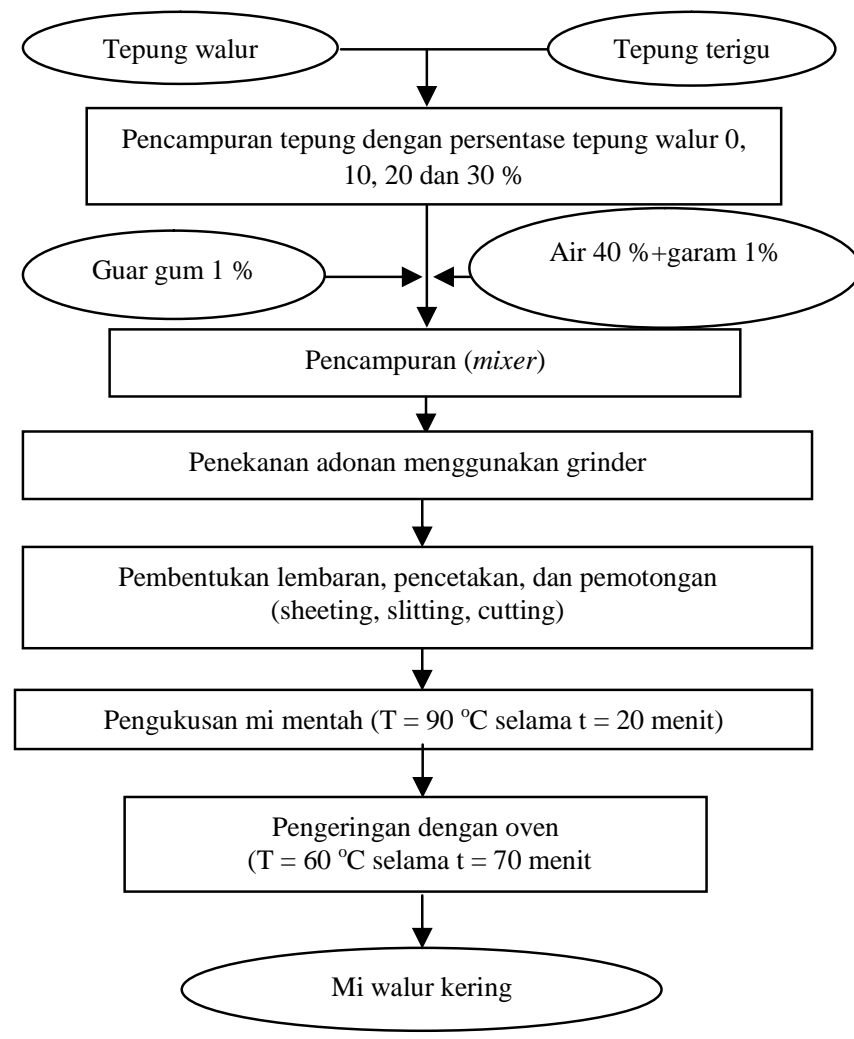

Gambar 1. Proses pembuatan mie walur kering

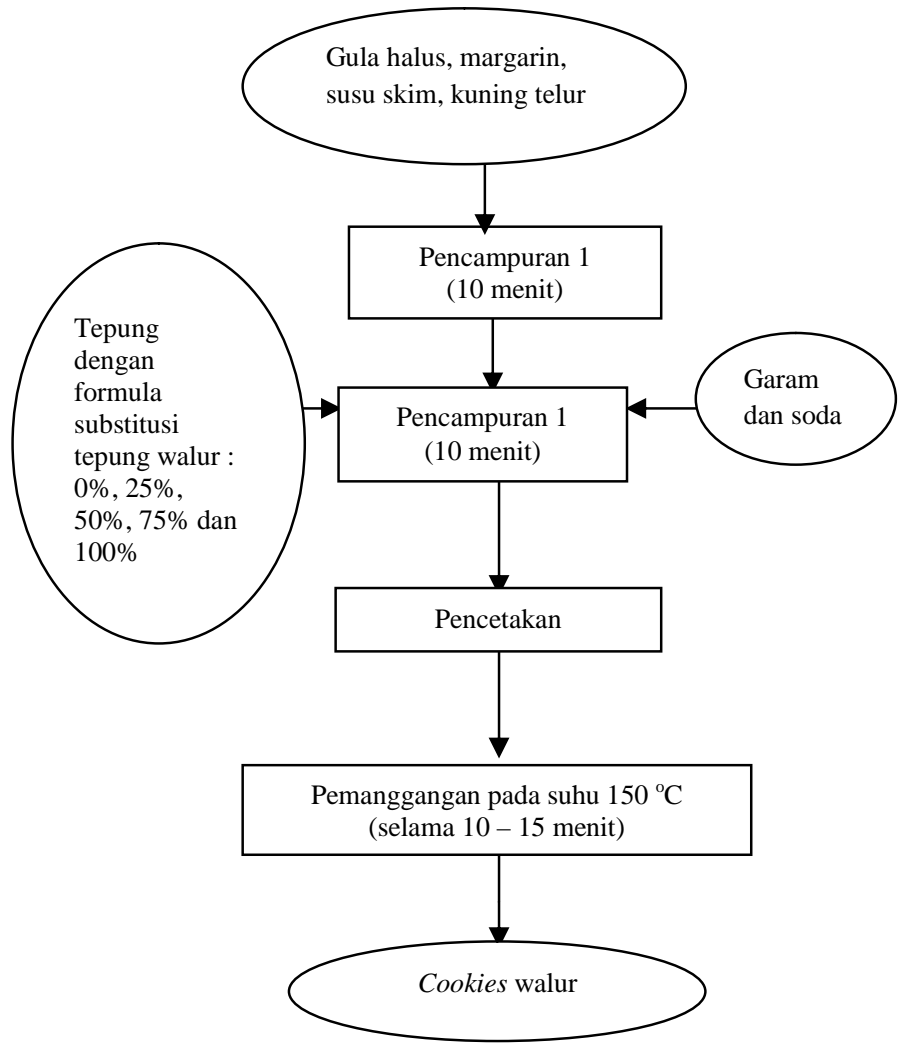

Gambar 6.Proses pembuatan cookies walur

\section{Hasil dan Pembahasan \\ Pengaruh substitusi tepung walur terhadap analisis organoleptik mie}

Parameter organoleptik yang diujikan pada produk mie dalam penelitian ini terdiri dari warna, kekenyalan, kelengketan, rasa, dan keseluruhan. Berdasarkan hasil analisis multivariate terhadap hasil uji kesukaan panelis, menunjukkan bahwa persentase substitusi tepung walur mempengaruhi tingkat kesukaan terhadap warna, kekenyalan, kelengketan, rasa dan keseluruhan. Histogram pengaruh substitusi tepung walur terhadap nilai kesukaan mie disajikan pada Gambar 3.

Warna merupakan kesan pertama yang diperoleh konsumen dari suatu produk pangan. Oleh karena itu, warna memegangang peranan yang penting dalam menentukan penerimaan konsumen terhadap produk tersebut. Menurut Meilgaard et al. (1999), warna merupakan salah satu atribut penampilan pada suatu produk yang sering kali menentukan tingkat penerimaan konsumen terhadap produk tersebut secara keseluruhan. Berdasarkan hasil pengujian organoleptik dapat diketahui bahwa tingkat kesukaan panelis terhadap atribut warna berkisar antara 3,76-6,12 atau agak tidak suka sampai suka. 


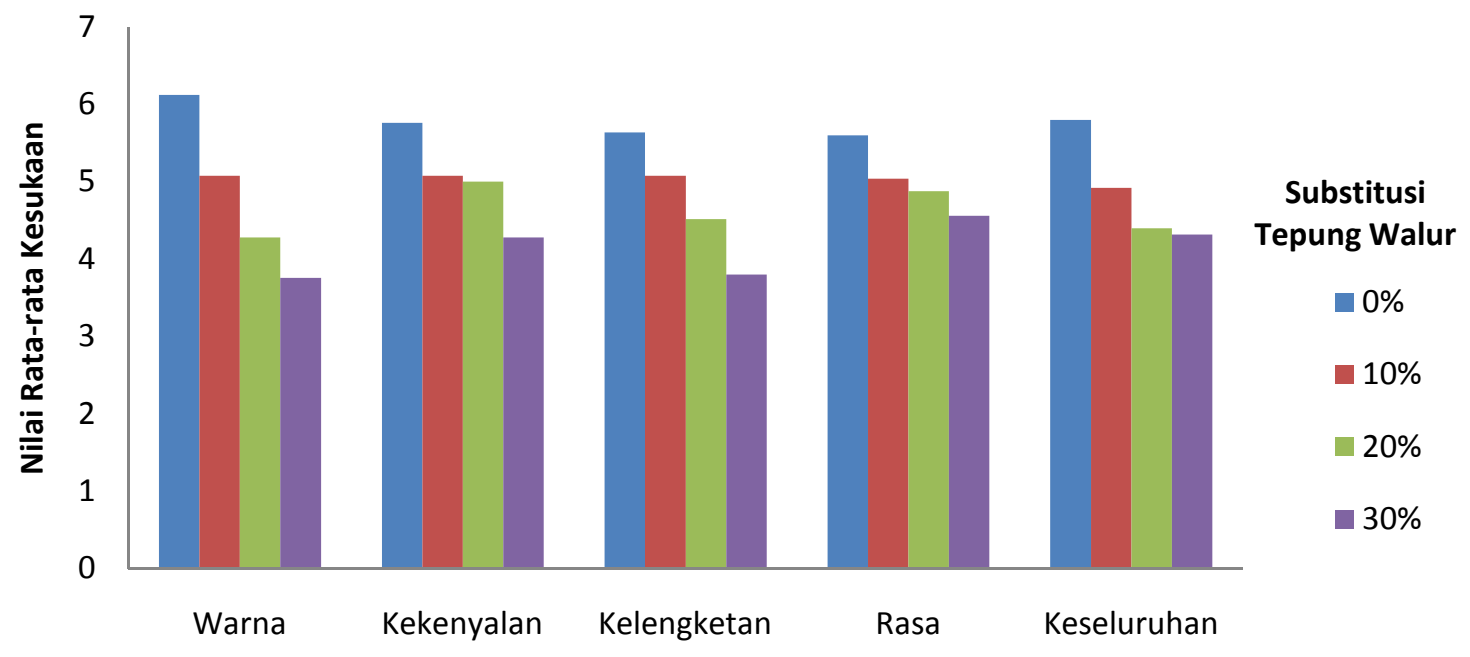

Gambar 3. Histogram pengaruh substitusi tepung walur terhadap nilai kesukaan mie.

Pada Gambar 3 terlihat bahwa peningkatan konsentrasi tepung walur dalam pembuatan cookies menurunkan tingkat kesukaan terhadap warna cookies. Sampai konsentrasi tepung walur $20 \%$ masih didapatkan tingkat kesukaan pada warna mie diatas netral atau mendekati agak suka. Berdasarkan hasil analisis multivarite, diketahui bahwa perbedaan rasio tepung walur dan tepung terigu yang digunakan mempengaruhi tingkat kesukaan panelis tehadap warna mie. Hasil uji lanjut Duncan menunjukkan bahwa setiap perlakuan substitusi memberikan pengaruh yang berbeda nyata. Foto produk mie substitusi tepung walur 0\% sampai 30\% disajikan pada Gambar 4.

Uji organoleptik kekenyalan bertujuan untuk mendapatkan tingkat kesukaan panelis terhadap kekenyalan produk mie yang dihasilkan dari setiap perlakuan. Berdasarkan hasil analisis multivariate, didapatkan bahwa perbedaan rasio tepung walur dan tepung terigu dalam pembuatan mie memberikan pengaruh yang berbeda nyata terhadap kesukaan panelis pada atribut kekenyalan. Berdasarkan hasil pengujian organoleptik dapat diketahui bahwa tingkat kesukaan panelis terhadap atribut kekenyalan berkisar antara 4,28 5,76 atau netral sampai agak suka. Meskipun secara umum terlihat bahwa, peningkatan komposisi tepung walur menurunkan kesukaan panelis terhadap kekenyalan mie tetapi sampai komposisi tepung walur tertinggi (30\%) memiliki tingkat kesukaan panelis terhadap kekenyalan diatas netral atau menuju suka.

Berdasarkan hasil pengujian organoleptik dapat diketahui bahwa tingkat kesukaan panelis terhadap atribut kelengketan berkisar antara 3,80 - 5,64 atau agak tidak suka sampai agak suka. Pada Gambar 3, secara umum terlihat bahwa peningkatan komposisi tepung walur menurunkan kesukaan konsumen terhadap atribut kelengketan dari produk mie. Sampai konsentrasi tepung walur 20\% masih didapatkan tingkat kesukaan pada warna mie diatas netral atau mendekati agak suka.

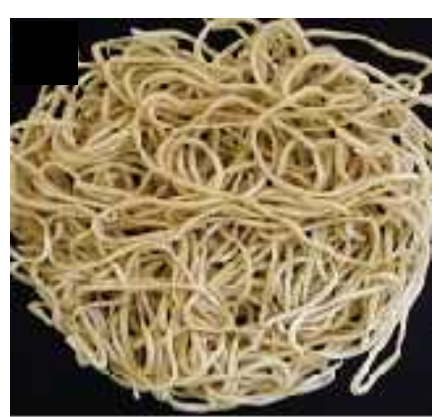

(b)

(a)

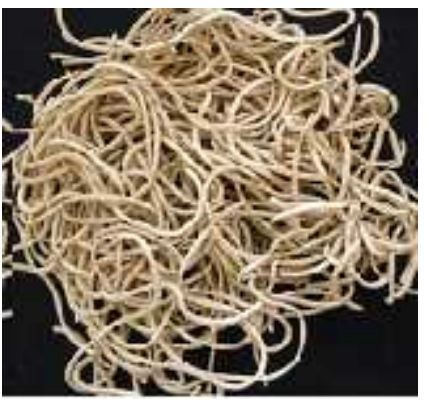

(c)
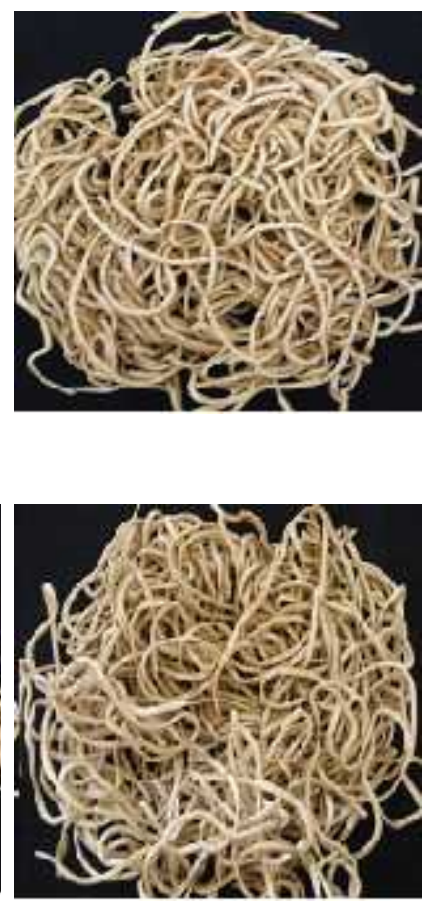

(d)
Gambar 4. Foto produk mie substitusi tepung walur $0 \%$ (a); $10 \%$ (b); $20 \%$ (c); $30 \%$ (d)

Berdasarkan hasil analisis multivariate didapatkan bahwa perbedaan rasio tepung walur dan tepung terigu yang digunakan untuk membuat mie memberikan pengaruh yang berbeda nyata terhadap kesukaan panelis pada atribut kelengketan produk mie pada selang kepercayaan 95\%. Hasil uji lanjut Duncan menunjukkan bahwa substitusi tepung walur $10 \%$ tidak berbeda nyata dengan substitusi $20 \%$ terhadap atribut kelengketan.

Rasa merupakan faktor yang menentukan tingkat kesukaan konsumen terhadap produk pangan. Atribut rasa 
meliputi asin, manis, asam, dan pahit. Sebagian dari atrtibut ini dapat terdeteksi dalam makan pada kadar yang sangat rendah. Rasa pada makanan sangat ditentukan oleh formulasi produk tersebut (Fellow 2000). Rasa dinilai dengan adanya tanggapan ransangan kimiawi oleh lidah. Berdasarkan hasil pengujian organoleptik dapat diketahui bahwa tingkat kesukaan panelis terhadap atribut rasa berkisar antara 4,56 - 5,60 atau netral sampai agak suka. Pada Gambar 3, secara umum terlihat tingkat kesukaan panelis terhadap rasa mie ini menurun dengan semakin tinggi persentase substitusi tepung walur tetapi masih berada diatas netral atau menuju agak suka. Hasil analisis multivariate menunjukkan bahwa perbedaan rasio tepung walur dan tepung terigu berpengaruh nyata pada skor kesukaan panelis terhadap rasa mie. Hasil uji lanjut Duncan menunjukkan bahwa tingkat kesukaan panelis terhadap rasa pada persentase substitusi 10\%, 20\% dan $30 \%$ tidak berbeda nyata.

Parameter keseluruhan (overall) digunakan dalam uji hedonik untuk mengukur tingkat kesukaan panelis terhadap keseluruhan atribut yang ada pada produk. Hal ini dilakukan karena hasil pengujian terhadap atribut tertentu saja menunjukkan nilai yang berbeda-beda. Dengan pengujian keseluruhan diharapkan dapat diketahui rasio tepung walur dan tepung terigu yang terpilih oleh konsumen. Berdasarkan hasil pengujian organoleptik dapat diketahui bahwa tingkat kesukaan panelis terhadap atribut keseluruhan berkisar antara 4,32 5,8 atau netral sampai agak suka. Pada Gambar 3, terlihat bahwa tingkat kesukaan panelis terhadap parameter keseluruhan menurun dengan semakin tingginya persentase substitusi tepung walur. Hasil analisis multivariate menunjukkan bahwa perbedaan rasio tepung walur dan tepung terigu yang digunakan untuk membuat mie memberikan pengaruh yang berbeda nyata tehadap tingkat kesukaan panelis terhadap atribut keseluruhan.

\section{Pengaruh Substitusi Tepung Walur terhadap Karakteristik Pemasakan Mie}

Analisis pemasakan terhadap mie tepung walur yang dilakukan dalam penelitian ini adalah kehilangan padatan selama pemasakan (KPAP) dan waktu optimum pemasakan. Pada saat pemasakan, sebagian padatan dari mie akan terpisah dari mie itu sendiri dan tersuspensi di dalam air pemasakan. Menurut Chen et al. (2003), secara kualitatif kejadian ini disebut dengan kehilangan padatan selama pemasakan (KPAP). Rata - rata nilai KPAP yang didapatkan dari penelitian ini berkisar antara 5,7 - 8,0 \%. Nilai KPAP tertinggi didapatkan pada substitusi tepung walur $30 \%$ dan terendah pada substitusi tepung walur $0 \%$. Histogram pengaruh substitusi tepung walur terhadap nilai KPAP mie disajikan pada Gambar 5.

Hasil analisis ragam menunjukkan bahwa, persentase substitusi tepung walur pada pembuatan mie memberikan pengaruh yang berbeda nyata terhadap nilai KPAP mie yang dihasilkan. Berdasarkan hasil analisis uji lanjut Duncan, didapatkan bahwa setiap perlakuan memberikan pengaruh yang berbeda nyata pada $\mathrm{p}<0,05$.
Nilai \% KPAP berhubungan dengan adanya ikatan antara amilosa dengan protein (Vignoux et al. 2005).

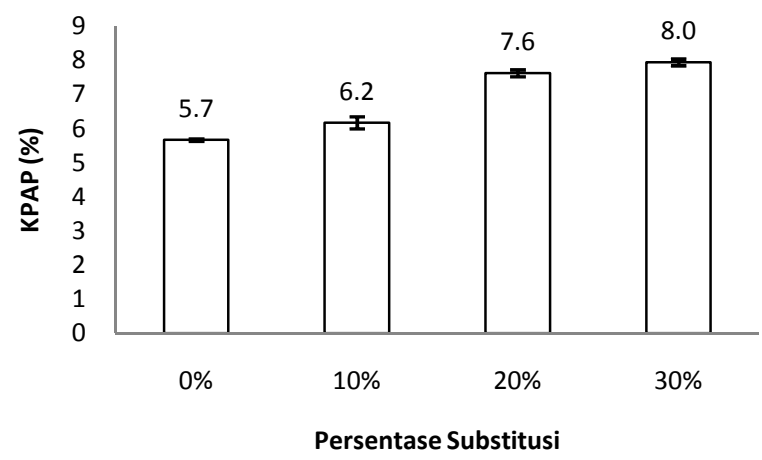

Gambar 5. Histogram pengaruh substitusi tepung walur terhadap nilai KPAP mie.

Berdasarkan Gambar 5, terlihat bahwa nilai KPAP mie semakin tinggi dengan semakin tingginya persentase substitusi tepung walur pada pembuatan mie. Kim et al. (1996) menyatakan bahwa nilai kemampuan pengembangan dan viskositas puncak yang tinggi juga menyebabkan tingginya nilai KPAP. Hal ini terjadi karena kemampuan pengembangan yang semakin tinggi dari suatu jenis tepung atau pati dapat menyebabkan granula patinya menjadi lebih mudah pecah dan menyebabkan kebocoran amilosa. Selain itu, Rayes-Duarte et al. (1996) menyatakan bahwa semakin lemah ikatan amilosa-protein (gluten), maka struktur keseluruhan mie akan melemah dan memudahkan materi padatan untuk larut selama pemasakan berlangsung. Apabila dibandingkan dengan hasil organoleptik, didapatkan bahwa pada substitusi tertinggi (30\%) dengan nilai KPAP $8 \%$ secara organoleptik masih dapat diterima dari segi kekenyalan, rasa dan keseluruhan.

Waktu optimum pemasakan dilakukan hingga mie yang dianalisis tidak menunjukkan garis putih ketika ditekan dengan menggunakan kaca. Waktu optimum pemasakan merupakan waktu yang dibutuhkan mie untuk kembali mengabsorpsi air sehingga tekturnya menjadi kenyal dan elastis seperti sebelum dikeringkan. Berdasarkan hasil analisis waktu optimum pemasakan yang disajikan pada Gambar 6, didapatkan rata - rata waktu optimum pemasakan mie berkisar antara 4,10 5,30 menit. Waktu optimum pemasakan mie pada persentase subtitusi tepung walur 30\%, secara organoleptik masih dapat diterima dari segi kekenyalan, rasa dan keseluruhan.

Gambar 6 memperlihatkan bahwa dengan semakin besarnya persentase substitusi tepung walur maka waktu optimum pemasakan mie akan semakin lama. Hasil analisis ragam menunjukkan bahwa persentase substitusi tepung walur dalam pembuatan mie memberikan pengaruh yang berbeda nyata terhadap waktu optimum pemasakan mie. Berdasarkan hasil uji lanjut Duncan didapatkan bahwa setiap perlakuan memberikan pengaruh yang berbeda nyata pada $\mathrm{p}<0,05$. Waktu optimum pemasakan dipengaruhi oleh beberapa faktor, yaitu 
ketebalan untaian mie (Huang dan Lai 2010) dan juga suhu gelatinisasi dari pati yang digunakan (Yadav et al. 2011).

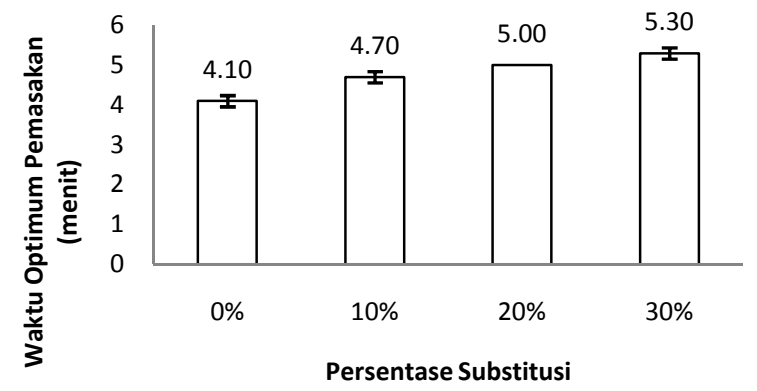

Gambar 6. Histogram pengaruh substitusi tepung walur terhadap waktu optimum pemasakan mie.

\section{Pengaruh substitusi tepung walur terhadap analisis tekstur mie}

Analisis tekstur mie bertujuan untuk melihat karakteristik fisik dari mie tersebut. Dalam penelitian ini, karakteristik fisik mie yang dianalisis adalah kekerasan dan gaya tarik. Tekstur merupakan salah satu parameter yang mendukung mutu suatu produk mie.

\section{Kekerasan}

Analisis kekerasan pada mie diukur dengan menggunakan alat Texture AnalyzerBrookfield Engineering TC3. Dengan uji tekstur ini dapat diketahui tingkat kekerasan mie pada setiap perlakuan. Tekstur yang dihasilkan pada mie sangat bergantung pada karakteristik fisik tepung yang digunakan. Karakteristik fisik tepung tersebut berupa kemampuan menyerap air, kekuatan gel dan profil gelatinisasi. Histogram nilai kekerasanproduk mie pada setiap perlakuan dapat dilihat pada Gambar 7.

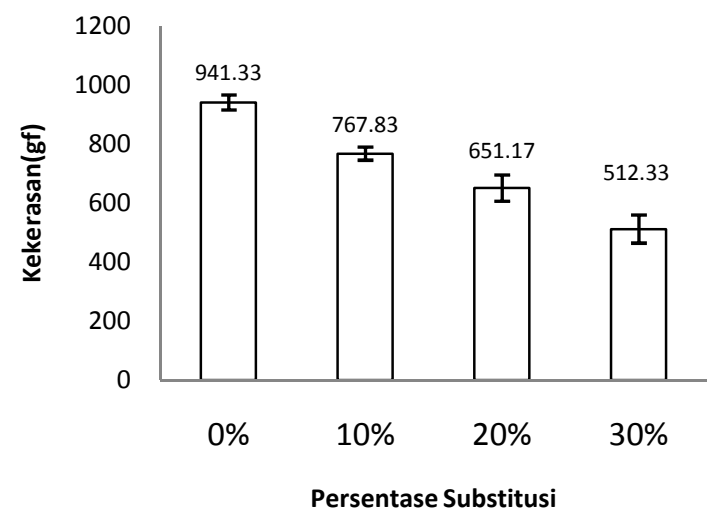

Gambar 7. Histogram nilai kekerasanproduk mie pada setiap perlakuan

Rata-rata nilai kekerasan produk mie yang dihasilkan berkisar antara 512,33 - 941,33 gf. Nilai kekerasanproduk mie tertinggi dan terendahberturut-turut adalah pada perlakuan $0 \%$ dan $30 \%$ (30\% walur). Hasil analisis ragam menunjukkan bahwa perbedaan rasio tepung walur dalam pembuatan mie memberikan pengaruh yang berbeda nyata terhadap nilai kekerasanmie pada selang kepercayaan $95 \%$. Dari hasil uji lanjut Duncan didapatkan bahwa setiap perlakuan substitusi tepung walur terhadap tepung terigu berbeda nyata pada $\mathrm{p}<0,05$. Secara umum dapat dilihat bahwa peningkatan rasio tepung walur akan menurunkan nilai kekerasan produk mie yang dihasilkan. Apabila dibandingkan dengan hasil organoleptik, didapatkan bahwa nilai kekerasan pada substitusi 30\% sebesar 512 gf secara organoleptik masih dapat diterima dari segi kekenyalan rasa dan keseluruhan.

Kekerasan merupakan daya tahan bahan untuk pecah akibat gaya tekan yang diberikan. Semakin besar gaya yang dibutuhkan (nilai puncak makin tinggi) maka menandakan kekerasan semakin meningkat. Faktor utama yang menyebabkan penurunan kekerasan adalah nilai KPAP (Vignoux et al. 2005). Semakin banyak padatan yang hilang selama pemasakan maka akan menyebabkan kekerasannya semakin menurun. Hal ini senada dengan data KPAP yang disajikan pada Gambar 5 yang menyatakan bahwa dengan semakin banyaknya substitusi tepung walur pada mie maka nilai KPAP-nya juga akan semakin besar. Menurut Shandu et al. (2010) mengatakan bahwa nilai kekerasan mie dipengaruhi oleh kemampuan pengembangan pati atau tepung penyusunnya. Tepung atau pati yang memiliki kemampuan pengembangan yang tinggi dapat menyebabkan penurunan kekerasan dan elastisitas mie.

\section{Gaya Tarik}

Gaya tarik atau tensile strength menunjukkan kekuatan elastisitas suatu bahan. Semakin tinggi nilai gaya tarik mie menunjukkan semakin tinggi nilai elastisitas mie tersebut. Artinya diperlukan kekuatan yang cukup besar untuk membuat untaian mie putus pada saat dilakukan penarikan. Nilai gaya tarik menggambarkan kemampuan maksimal mie untuk menahan gaya tarikan dengan besaran tertentu. Analisis gaya tarik pada produk mie ini menggunakan alat Texture AnalyzerBrookfield Engineering TC3. Histogram nilai gaya tarik produk mie pada setiap perlakuan dapat dilihat pada Gambar 8.

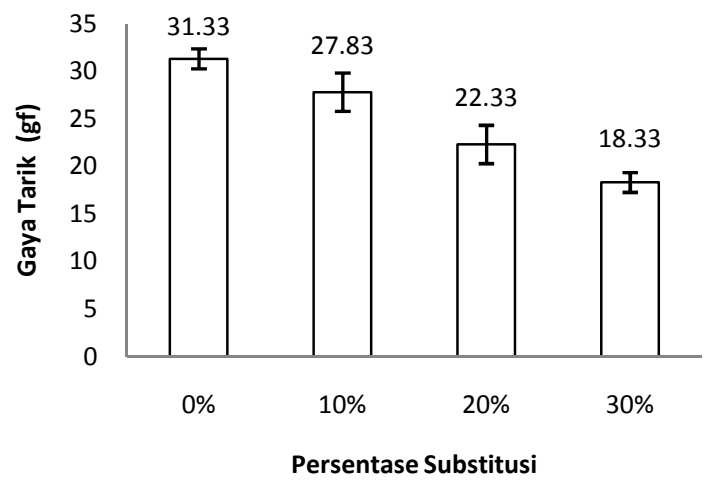

Gambar 8. Histogram nilai gaya tarik produk mie pada setiap perlakuan 
Rata-rata nilai gaya tarik produk mie pada setiap perlakuan berkisar antara 18,33 - 31,33 gf. Nilai gaya tarikproduk mie tertinggi dan terendah berturut-turut dihasilkan oleh perlakuan $0 \%$ dan $30 \%$.

Hasil analisis ragam menunjukkan bahwa perbedaan persentase substitusi tepung walur yang digunakan dalam pembuatan mie memberikan pengaruh yang berbeda nyata terhadap nilai elastisitas mie pada selang kepercayaan 95\%. Dari hasil analisis Duncan didapatkan bahwa setiap perlakuan berbeda nyata pada $\mathrm{p}<0,05$. Dengan demikian, dapat dikatakan bahwa peningkatan komposisi tepung walur dalam pembuatan mie menurunkan nilai elastisitas produk mie yang dihasilkan. Namun, nilai gaya tarik mie pada persentase substitusi tertinggi (30\%) sebesar 18,33 gf secara organoleptik masih dapat diterima dari segi kekenyalan, rasa dan keseluruhan. Menurut Tan et al.
(2009), nilai gaya tarik dipengaruhi oleh kemampuan pengembangan. Tepung atau pati yang memiliki kemampuan pengembangan yang tinggi akan memiliki nilai gaya tarik yang semakin kecil.

\section{Pengaruh substitusi tepung walur terhadap analisis organoleptik cookies}

Parameter organoleptik yang diujikan dalam penelitian ini terdiri dari warna, aroma, kerenyahan dan keseluruhan. Hasil analisis multivariate terhadap uji kesukaan cookies menunjukkan bahwa penambahan tepung walur pada cookies mempengaruhi tingkat kesukaan panelis terhadap semua parameter yang diujikan. Histogram pengaruh substitusi tepung walur terhadap kesukaan cookies disajikan pada Gambar 9.

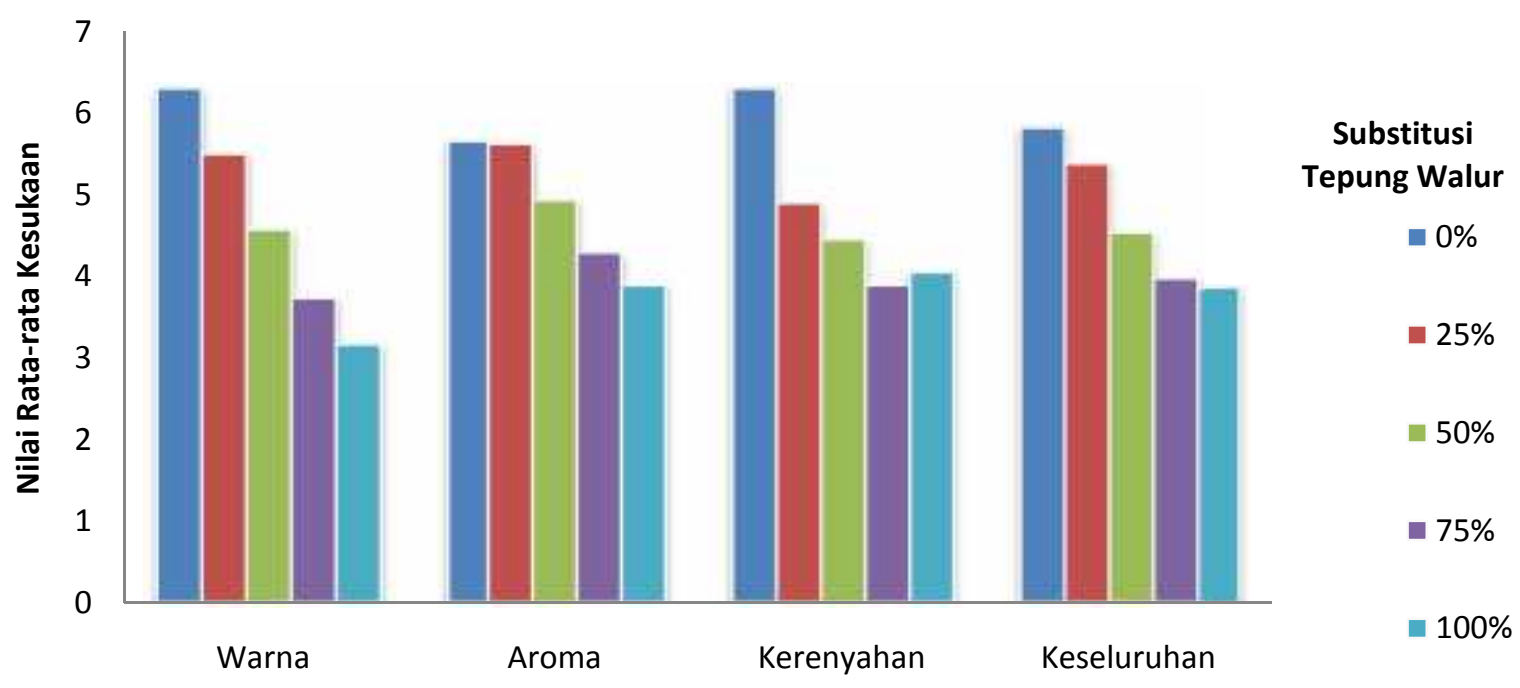

Gambar 9. Histogram pengaruh substitusi tepung walur terhadap nilai kesukaan cookies

Warna cookies dipengaruhi oleh bahan-bahan yang digunakan dalam pembuatan cookies terutama oleh lemak, gula, tepung dan telur. Berdasarkan hasil uji organoleptik, skor rata-rata kesukaan panelis terhadap warna cookies berkisar antara 3,16 - 6,28 atau agak tidak suka sampai suka. Pada Gambar 9 dapat dilihat bahwa peningkatan konsentrasi tepung walur dalam pembuatan cookies menurunkan tingkat kesukaan terhadap warna cookies. Sampai konsentrasi tepung walur $50 \%$ masih didapatkan tingkat kesukaan pada warna cookies diatas netral atau mendekati agak suka. Hasil analisis multivariete, diketahui bahwa perbedaan rasio tepung walur dan tepung terigu yang digunakan berpengaruh nyata terhadap warna cookies walur. Uji lanjut Duncan menunjukkan bahwa substitusi $75 \%$ dan 100\% tidak memberikan pengaruh yang berbeda terhadap parameter warna cookies. Foto produk cookies substitusi tepung walur 0\% - 100\% disajikan pada Gambar 10.
Setser (1995) menjelaskan aroma merupakan hasil ransangan kimia dari syaraf-syaraf olfaktori yang berada dibagian akhir dari rongga hidung. Aroma merupakan bau yang dicium karena sifatnya yang volatil. Aroma pada cookies dipengaruhi oleh beberapa bahan baku yang digunakan dalam pembuatan cookies antara lain adalah lemak, susu, telur, dan tepung. Skor rata-rata uji organoleptik kesukaan terhadap aroma berkisar antara 3,88 - 5,64 atau agak tidak suka sampai agak suka. Peningkatan konsentrasi tepung walur dalam cookies menurunkan tingkat kesukaan terhadap aroma (Gambar 9). Pada konsentrasi tepung walur $75 \%$ masih didapatkan tingkat kesukaan pada aroma diatas netral. Berdasarkan hasil analisis multivariate, didapatkan bahwa perbedaan ratio tepung memberikan pengaruh yang berbeda nyata terhadap tingkat kesukaan panelis pada aroma cookies. 


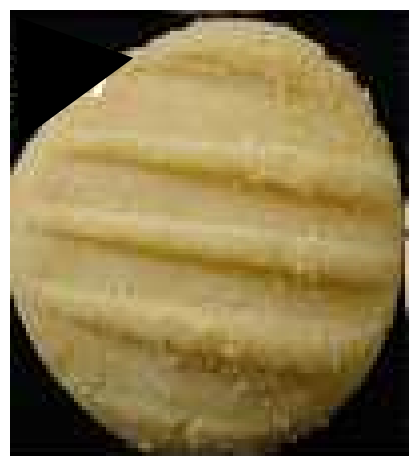

(a)

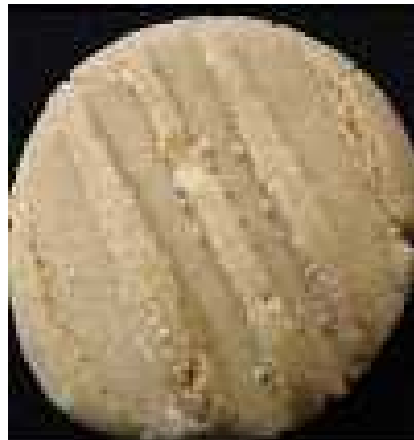

(b)

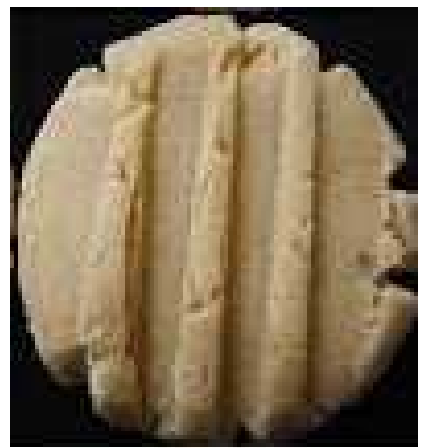

(c)

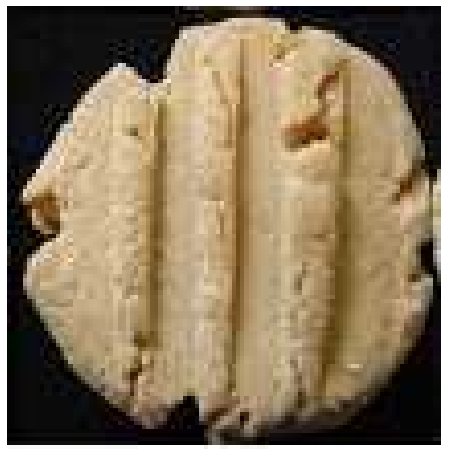

(d)

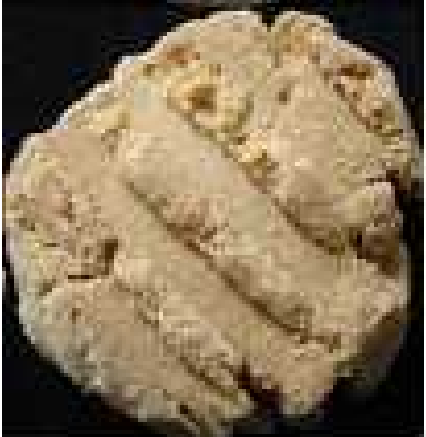

(e)

Gambar 10. Foto produk cookies substitusi tepung walur 0\% (a); $25 \%$ (b); $50 \%$ (c); 75\% (d); $100 \%$ (e)

Kerenyahan menggambarkan karakteristik tektur dari cookies. Pada cookies, tekstur merupakan atribut produk yang cukup penting karena cookies biasanya dinilai dari teksturnya. Berdasarkan hasil uji organoleptik, skor rata-rata kesukaan panelis terhadap kerenyahan cookies berkisar antara 3,88 - 6,28. Pada Gambar 9 dapat dilihat bahwa tingkat kerenyahan cookies walur menurun dengan semakin tingginya konsentrasi tepung walur dalam pembuatan cookies. Pada konsentrasi tepung walur $50 \%$, masih didapatkan tingkat kerenyahan cookies diatas netral. Hasil analisis multivariate menunjukkan bahwa perbedaan rasio tepung walur dengan tepung terigu yang digunakan pada pembuatan cookies berpengaruh nyata pada skor kesukaan panelis terhadap kerenyahan cookies walur.

Berdasarkan hasil pengujian organoleptik dapat diketahui bahwa skor tingkat kesukaan panelis terhadap parameter keseluruhan berkisar antara 3,84 - 5,80 atau agak tidak suka sampai agak suka. Secara umum dapat dilihat bahwa peningkatan persentase substitusi tepung walur akan menurunkan tingkat kesukaan panelis terhadap parameter keseluruhan. Pada konsentrasi tepung walur $50 \%$, masih didapatkan tingkat kesukaan panelis diatas netral atau menuju agak suka. Hasil analisis ragam menunjukkan bahwa perbedaan rasio tepung walur dan tepung terigu memberikan pengaruh yang berbeda nyata tehadap tingkat kesukaan panelis secara keseluruhan.

\section{Pengaruh substitusi tepung walur terhadap kekerasan cookies yang dihasilkan}

Cookies memiliki ciri utama berupa teksturnya yang renyah. Menurut Piazza dan Massi (1997), kerenyahan dipengaruhi oleh sejumlah air yang terikat pada matriks karbohidrat yang mempengaruhi pergerakan relatif dari daerah kristalin dan amorf. Kerenyahan cookies dipengaruhi oleh komposisi utama cookies, proses pemanggangan dan jenis kemasan. Kerenyahan merupakan kriteria mutu penting dari berbagai produk sereal. Kerenyahan produk pangan berkadar air rendah dipengaruhi oleh kandungan air dan akan hilang karena adanya plastisasi strtuktur fisik oleh suhu atau air. Pengujian kerenyahan pada penelitian ini menggunakan alat Texture AnalyzerBrookfiel Engineering TC3. Histogram nilai kekerasan dari cookies walur dapat dilihat pada Gambar 11.

Rata-rata nilai kekerasan dari cookies walur berkisar antara 523,00 - 2.306,67 gf. Nilai kekerasan tertingi dan terendah berturut-turut adalah pada cookies dengan komposisi walur $100 \%$ dan pada cookies dengan komposisi tepung walur $0 \%$ (100\% terigu). Hasil analisis ragam menunjukkan bahwa perbedaan rasio tepung walur dan tepung terigu dalam pembuatan cookies berpengaruh nyata terhadap nilai kekerasanproduk cookies pada selang kepercayaan $95 \%$. Hasil uji lanjut Duncan menunjukkan bahwa setiap perlakuan memberikan 
pengaruh yang berbeda nyata pada $\mathrm{p}<0,05$. Secara umum dapat dilihat bahwa, peningkatan rasio tepung walur pada pembuatan cookies akan meningkatkan nilai kekerasandari cookies yang dihasilkan. Apabila dibandingkan dengan hasil organoleptik, nilai kekerasan cookies pada persentase substitusi 50\% sebesar $1.596 \mathrm{gf}$ masih dapat diterima secara organoleptik.

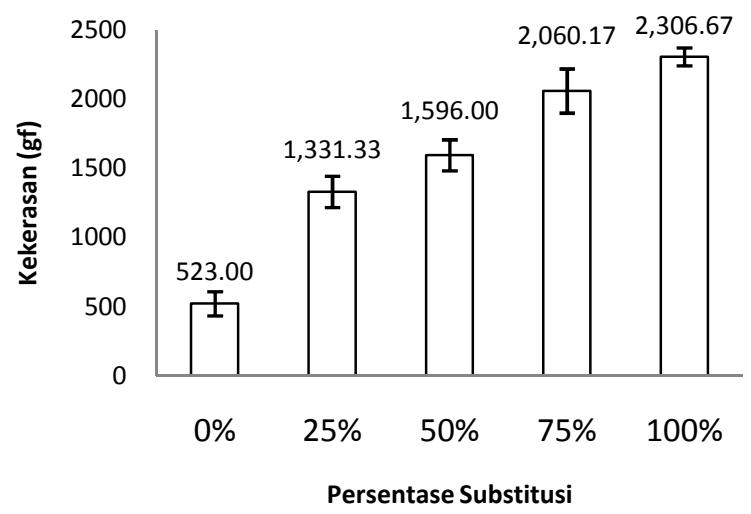

Gambar 11. Histogram nilai kekerasandari cookies walur

Nilai kekerasan cookies dipengaruhi oleh beberapa faktor, yaitu kandungan lemak (Zoulius et al. 2002), kemampuan lemak dalam menangkap udara pada saat pencampuran (Kamel 1994) dan kemampuan pengembangan dari pati tepung penyusunnya (Singh et al. 2003). Dalam penleitian ini, kemampuan pengembangan dari pati atau tepung menjadi faktor yang mungkin menyebabkan perbedaan kekerasan dari cookies, sedangkan kandungan lemak pada setiap perlakuan adalah sama. Kemampuan pengembangan pati berfungsi untuk membentuk zona udara dengan volume tertentu, sehingga kemampuan pengembangan yang berbeda akan menghasilkan zona udara dengan volume yang berbedabeda yang akan mempengaruhi kekerasan dari cookies yang dihasilkan.

\section{Kesimpulan}

Hasil analisis multivariate terhadap uji kesukaan mie menunjukkan bahwa penambahan tepung walur padamie mempengaruhi tingkat kesukaan panelis pada parameter warna, kekenyalan, kelengketan, rasa dan keseluruhan. Parameter warna dan kelengketan pada substitusi $30 \%$ memiliki nilai rata-rata dibawah netral atau menuju agak tidak suka sedangkan untuk parameter kekenyalan, rasa dan keseluruhan pada substitusi $30 \%$ masih memiliki nilai rata-rata kesukaan diatas netral atau menuju agak suka. Pada substitusi tertinggi (30\%) ini didapatkan nilai KPAP (Kehilangan padatan selama pemasakan) sebesar $8 \%$, waktu optimum pemasakan mie 5,30 menit, nilai kekerasan sebesar 512 gf dan nilai gaya tarik mie sebesar 18,33 gf. Hasil analisis multivariate terhadap uji kesukaan cookies menunjukkan bahwa penambahan tepung walur pada cookies mempengaruhi tingkat kesukaan panelis pada semua parameter yang diujikan. Parameter-parameter yang diujikan adalah warna, aroma, kerenyahan dan keseluruhan. Substitusi tepung walur pada pembuatan cookies dapat diterima sampai $50 \%$ karena nilai rata-rata kesukaannya masih berada diatas netral atau menuju agak suka. Dimana, nilai kekerasan cookies pada persentase substitusi ini 50\% sebesar 1.596 gf.

\section{Daftar Pustaka}

Chen Z, Schols HA, Voragen AGJ. 2003. Starch granule size strongly determines starch noodle processing and noodle quality. Journal of Food Science 68(5): 1584-1589.

Fellow PJ. 2000. Food Processing Technology: Principle and Practice 2nd Ed. England: CRC Press.

Huang YC, Lai HM. 2010. Noodle quality affected by different cereal starches. Journal of Food Engineering 97: 135 - 143.

Kamel BS. 1994. Creaming, emulsions, and emulsifiers. In Hamed Faridi (Ed.), The science of cookie and cracker production. New York: Chaman \& Hall.

Kim YS, Wiesenborn DP, Lorenzen JH, Berglund P. 1996. Suitability of Edible Bean and Potato Starches for Starch Noodle. Cereal Chem 73(3): 302-308.

Meilgaar M, Civille GV, Carr BT. 1999. Sensory Evaluation Techniques $3^{\text {rd }}$ Ed. Boca Raton: CRC Press.

Ochtsuki T. 1968. Studies on reverse carbohydrate of flour Amorphophallus spesies with special refference to mannan. Botanical Magazine Tokyo 8: 119-129.

Piazza L, Massi P. 1997. Development of crispiness in cooking during baking in an industrial oven. Cereal Chemistry. 74(2): 135-140

Rayes-Duarte P, Mock CM, Satterlee LD. 1996. Quality of spaghetti containing buckwheat, amaranth, and lupin flours. Cereal Chemistry 73: $381-387$.

Sadhu, Maninder, Mukesh. 2010. Studies on noodle quality of potato and rice starches and their blends in relation to their physicochemical, pasting and gel texture properties. Food Science an Technology 2010; $43: 1289$ - 1293 .

Setser CS. 1995. Sensory Evaluation. Didalam: Kramel dan Stauffer. Advances in Baking Technology. Glasgow: Blakie Academic and Proffesional.

Singh, Narpinder, Sharmab. 2003. Physicochemical, rheological and cookie making properties of corn and potato flours. Food Chemistry 83: 387 - 393.

Sukri N. 2014. Pengaruh Penambahan Natrium Metabisulfit Terhadap Karakteristik Tepung Walur (Amorphophallus campanulatus var. Sylvetris). Jurnal Teknotan Vol 8.3: 1275-1281 
Tan HZ, Li ZG dan Tan B. 2009. Starch noodles: History, classification, materials, processing, structure, nutririon, quality evaluating and improving. Food Research International 42: 551-576.

Vignaux $\mathrm{N}$ et al. 2005. Quality of spaghetti made from full and partial waxy durum wheat. Cereal Chem 82:93- 100 .

Yadav BJ, Ritika BY, Mahesh K. 2011. Suitability of pigeon pea and rice starches and their blends for noodle making. Food Science and Technology 44: $1415-1421$.

Zoulias EI, Oreopoulou V, Tzia C. 2002. Textural properties of low-fat cookies containing carbohydrate- or protein-based fat replacers. Journal of Food Engineering 55: 337-342. 